\title{
Developmental status of Indravati Dam oustees in India: A Human Development Index assessment
}

\author{
Ipsita Das ${ }^{*}$, H. R. Tewari \\ (Department of Humanities \& Social Sciences, Indian Institute of Technology, Kharagpur, West Bengal India
} 721302)

\begin{abstract}
Resettlement concerns arising by construction of dams have always remained pivotal in a country's developmental aspirations. Though, governmental agencies upfront provide a well schemed rehabilitation package for the resettled population, instances of disparity between the proposed package and its proper implementation is noted. Most of the reports and studies are subjectively biased as there is a lack of objective tool for assessing the rehabilitation schemes. We have used Human Development Index (HDI) to measure the effectiveness of rehabilitation package implementation on the displaced population of Indravati dam project in India. Data was collected by questionnaire from 300 households of 24 villages and assessment for HDI was estimated with three indices, that is education, life expectancy and real per capita income. Qualitative assessment measures were evaluated on social, educational, health care and financial aspects. The results showed that the HDI of the oustees $(0.335 \pm 0.010)$ were much lower than that of the people of India $(0.558)$. The qualitative results revealed deterioration in the quality of life for respondents in the post displacement period comparing to pre displacement period. Our study emphasizes the value added to the assessment of the rehabilitation policy implementation using the advance analytical tool of HDI measurement.
\end{abstract}

Key words: Dam, displacement, oustees, rehabilitation, resettlement,

\section{Introduction}

"Dams are the temples of a modern India" said Jawaharlal Nehru, the first Prime Minister of independent India.[1] The number of dams constructed at one point in history reflected as an indicator of nation development. Dams are much crucial apart from generating electricity, in preventing floods and irrigating agricultural fields. Importance of dams cannot be over emphasized. It is viewed that construction of dams is crucial for economic and social development of a country. Dam's play contradictory role, one as a pillar for estimating nations growth on the other a major man made disaster leading to massive population displacement. $[2-4]$

World Commission on Dams with its worldwide survey reported that dams were the epitome of public welfare projects, providing a long term planned investments with multiple benefits being delivered. The benefits of dams would lead to regional development and job creation resulting in economic growth of a country.[4,5]

India is one of the biggest dam builders in the world.[6, 7] Apart from causing regional development and creating jobs, on a downside large dams in India have displaced 16-38 million people as an estimate. The level of displacement has increased substantially after 1990 with the construction of multiple projects across the country. The cause of massive displacement is enormous across the nation.[6-10]

Case studies related to dam projects dominate the literature on development-induced displacement. In their volume Picciotto, Van Wicklin, and Rice include six case studies on dam displacement and resettlement, including that in the Upper Krishna Project in India, the Shuikou and Yantan dam projects in China, the Pak Mun Dam Project in Thailand, the Kedung Ombo Dam Project in Indonesia, the Itaparica Dam in Brazil, and the Nangbeto Dam in Togo.[11] In India approximately 36 million people have been adversely affected with construction of dams since independence to 2004 of which $40 \%$ belong to tribal population.[12-17]

Among all the developmental projects, dam cause the largest physical dislocation, submerge vast areas of agricultural lands, un-employment and hence, lead to social pressure among oustees in villages. According to the World Bank reports dams are the biggest factor (approx 66\%) for causing displacement.[18, 19] Moreover, World Bank assisted projects comprise only 3\% of dam associated displacement.[4, 6, 20-26] Most of the studies are focused on the locally occurring displacement at the dam site, though it is well known fact that large dams have vast impacts on social, financial and environmental aspects. World Commision on Dams as well as McCully provided a comprehensive report of the direct and indirect effects of large dams on human habitat. [26] Bartolome et. al on the other hand goes a step ahead and viewed about displacement along with resettlement and rehabilitation strategies. [27] Bartolome also suggests means and ways to improve accountability in assessment of resettlement scheme along with ways to implement the same successfully. 
Displacement of human population has always been traumatic, dismantling the agricultural production system, loss of employment, disorganization of social systems and breakdown of associations. Displacement invoked by dams dismantles the agricultural production system, caused loss of employment, disorganised social system and network, disjoint kinship groups, wiped away the formal and informal associations, changed the occupational pattern, degraded the environment, deteriorated health and food security. Besides, it uproots people from their cultural practices and traditional occupations [10, 28, 29]. Irrespective of the causes the degree of suffering experienced by displaced people cannot be quantified objectively. Displacement of people submerged under hydel power project dams is a classic case where hardships are imposed on people in lieu of government developmental project planning. $[8,30,31]$

There exist great discrepancies between the claims made by the government/ policy makers of the rehabilitation schemes and views of the oustees. The amount given by the government either in cash or in land as compensation is arbitrary since the market value of the land owned by the oustees is not calculated. Further whatever cash is given as compensation is misutilized since the oustees are used to dealing with small cash only. Prior to the implementation of dams project, government initiates rehabilitation packages with a purpose to provide reasonable living to dam oustees. The scale of displacement is directly proportional to the size of the dam being constructed, topography of the water shed, land in the vicinity of reservoir and the density of the population.[32, 33] Hence, this compensatory strategy eventually deteriorates the living conditions of the oustees. The displacees narrated their trauma and suffering in the resettlement villages by pointing to the demerits of the rehabilitation schemes. $[1,7,12,34-36]$ Whereas the governmental agencies on the other hand provide details of the success of their resettlement policies. These are informations based on the interviews and documentation of qualitative questionaires.

There are several reports and studies on dam rehabilitation, but unfortunately they remained biased and subjective based reporting of the author.[37, 38] In order to have an objective assessment of the implementation of the rehabilitation and resettlement schemes of governmental agencies the study uses Human Development Index (HDI).[35, 39-41] The success of the rehabilitation is considered when the oustees have similar or better living and essential resources in new locations as compared to pre-displaced locations.

We have used three indicators of HDI that is education, life expectancy and real per capita income to objectively assess the extent of rehabilitation of the oustees. We have assessed the extent of rehabilitation using HDI on oustees of Upper Indravati Hydro-Electric project. We have also used HDI tool for intra-village comparison using the three parameters (education, life expectancy and real per capita income). HDI was used to determine the differential outcome of the rehabilitation scheme based on the villages. Moreover, HDI ranks the villages in order of their HDI values. We have also compared HDI of all villages of the state of Orissa with the HDI of the state. Our study revealed that HDI of all the villages were very low compared to HDI of the state of Orissa.

\section{Data collection and methodology}

The Upper Indravati Hydro-Power project was initiated with World bank financial assistance in 198384 in the south western region of the state of Orissa in India, involving tri-districts of Koraput, Nowrangpur and Kalahandi. The project got functional in 1999 with the generation of electricity. A total of 97 villages were affected from district of Koraput (34 villages), Nowrangpur (28) and Kalahandi (35 villages). Of the 97 villages, 65 were completely submerged and 32 remained partially affected. As per government records, a total of 5477 families were displaced phase-wise from 1989 to 1992. Most of the displaced people were from the lower income group and tribal origin. Few of the displaced families were resettled in small patches of land, whereas others were paid compensatory cash with which they moved to different places. In this study data was collected from household of 300 oustees. Their distribution is 76 from Koraput, 108 from Nowrangpur, and 116 from Kalahandi district. The selection of the respondents was based on random sampling.

Interview schedule and observational methods were used as tools for data collection. The household chiefs or adults (>18 yrs) were interviewed with the help of open-ended Interview Schedule. Qualitative information were also collected. Secondary data for the study were collected from various governmental reports, official documents, opinions and views of officials.

\subsection{Qualitative Report:}

Qualitative reports were collected from all the 300 households, in an attempt to obtain the views of the oustees on governmental policies on rehabilitation and resettlement and their living conditions in the resettlement areas. The opinions obtained across the 300 villages had a very similar view that is failure in governmental approach. The oustees livelihood as well as their social life were completely shattered after displacement. They were unable to fulfil their family requirements with meagre compensation and moreover, they were looked down by the neighbouring villages for their state of destitute. 
Data were collected to evaluate the qualitative effects in social life, educational profile, housing, financial structure of the oustees before and after displacement.

\subsubsection{Social life:}

Social stratification leads to sectorization of the society into different groups or sections. The introduction of this system in Indian society is termed as "caste system". Though caste system is very stringent in the villages, it does not seem to be relevant in the resettlement villages. Financial and social hardships must have been instrumental in bringing the oustees close to each other. An overview of caste distribution in resettlement areas show, shows that most of the oustees were belonging to lower caste $(72.3 \%)$ and the rest belongs to middle caste (27.7\%), but none to the upper caste. Moreover, our data showed that the basic social institution, family was fragmented down in the oustees, shows that with most of the displaced population having nuclear family (72\%) followed by joint family $(22.5 \%)$. The extended family almost disappeared with some sparsely in the resettled villages (5.5\%). The data revealed that because of financial burden, the extended and joint families were broken down to nuclear families. Prior to displacement, the extended (16.4\%) and joint families (39.8\%) together constituted more than half of the population $(56.2 \%)$, and the rest were nuclear families $(43.8 \%)$. The acceptance and practice of family planning has deteriorated in the oustees' postdisplacement (77\%) as compared to pre-displacement (40.6\%).

Recreational activities which play a vital role in the social lives of people were also evaluated in the oustees. There was a significant decline in participation among the oustees in recreational activities, post displacement shows $58 \%$ from $93.2 \%$ in pre-displacement. This decrease could also be directly proportional to the financial comfort zone of the oustees. There was a drastic decrease in organizing and/or participating in social festivals (32.7\%), membership of political parties (14\%), organizing demonstrations and meetings (29.6\%) and attending such meetings (27.4\%) in post displacement era in comparison with $67 \%, 44 \%, 57.3 \%$ and $72.6 \%$ respectively, in the pre displacement period. (Table-1)

\subsubsection{Educational profile:}

Educational profile was done based on the interviews and data collected for all the 300 households. Most of the oustees were uneducated $(82.3 \%)$ with around $13.7 \%$ with primary level education and $4 \%$ secondary level education in post-dam resettlement areas. In the pre-displacement period the number of uneducated people was $52.1 \%$, followed by primary level education with around $37.8 \%$ and the rest of population remained with secondary level education $(10.1 \%)$. Majority of the educated people post dam period had a desire for higher education (19.7\%), this was significantly low in the pre dam period (6.2\%). This increase in the interest for higher education could be driven by displacement induced joblessness in the oustees. The major reason for not showing interest in education among oustees was revealed to be the financial constraint (2.4\%) followed by impression of waste of money and time (1.7\%), then lack of interest (1.3\%) and thought that it doesn't serve any purpose (1.0\%). There was a mild decrease in the status of children's education among oustees compared to prior displacement. It's been seen that prior to displacement $24 \%$ and $13.3 \%$ of boys and girls were educated that decreased to $19.7 \%$ and $10.3 \%$, respectively and rest remained uneducated. Around $70 \%$ of the respondents were keen in educating their children, where as this number was nearly half prior to displacement. Most of the parents wanted to teach their children for employment (36\%) followed by better living (28.4) and general awareness (5.3\%), whereas in the pre displacement period parents were keen to educate their children for better living $(42.2 \%)$, followed by general awareness $(17 \%)$ and then employment (12.8). It could have been that parents in the pre displacement period wanted the in children to take care of the family profession such as agriculture. The respondents preferred boys to have more general education (15.4\%) and girls to get vocational education (5.6\%). (Table-2)

\subsubsection{Health profile:}

Health care services play a vital role in the human wellbeing. The healthcare systems in villages are Primary Health Center (PHC), Hospitals and Aganwadi workers (trained women for health care of women and children). There was a steep decrease in the numbers of PHC in post displacement period to 10 from 21, though the number of hospitals remained the same and there was a slight decrease in the number of Aganwadi workers to 42 from 48 prior to displacement. Most of the oustees visited Aganwadi workers for affordability and availability (40\% approx), though the still $23.7 \%$ visited PHC. There was a significant decrease in the respondents visiting PHC prior to displacement $(57.8 \%)$ to post displacement $(23.7 \%)$. There was a significant increase in parasitic and bacterial infections in post displacement with a drastic increase in malaria, tuberculosis and diarrhoea. There wasn't much difference in the physiological pathologies such as heart problems, delivery related problem or other general health. (Table-3) 


\subsubsection{Financial profile:}

Displacement lead to decrease in farming with a concurrent increase in labor and business related jobs. There was also an increase in self employment activities with retail business leading the options. Prior to displacement $90 \%$ of respondents were farmers, 3-5\% engaged in labour and business activities. After displacement farmers were 71\% and 10-12\% labourers and businessman. Most of the respondents earned 7-10\$ per month in post resettlement, whereas prior to resettlement most of them earned 18-20\$ per month. There was an increase in the other sources of income among oustees as the income from agriculture wasn't sufficient. The other jobs were carpentry work, cattle rearing, basket making and so on. Majority of the respondents were unable to meet their expenditure from the family income in post displacement (42\%) and major part of their money was spent on food. Prior to displacement the respondents were able to meet the basic needs of clothing, food and shelter, where as post displacement the clothing and food were more affected. There was an increase in loans (51\%), extra labour (8.6\%) and compromising the needs. Financial loans were mostly taken to suffice monetary issues for social occasions and meet medical issues. Prior to displacement $63 \%$ were able to save money which reduced to $30.6 \%$ post displacement. The extent of savings also reduced drastically after the displacement. (Table-4)

We used questionnaire and interviews for assessing the quality of life of oustees in post displacement. The results primarily revealed deterioration in the quality of life for respondents in the post displacement period comparing to pre displacement period. The qualitative analysis does not provide a quantitative value to the extent of damage caused in the life of oustees. Hence, we used Human Development Index to calculate the status of development among the oustees of dam induced displacement.

\section{Human Development Index}

Human development index is a combinatorial outcome of qualitative and quantitative development based on physical, mental as well as psychological status. Human Development Reports (HDR) of UNDP (United Nations Development Program) is widely accepted measure in defining the welfare of nations. UNDPs well known definition of development "enlarging people's choice lead to the development of Human Development Index (HDI). HDI is a measure of composite combination of indicators such as life expectancy, educational attainment and income. [31, 39-41]

HDI has been used to measure human development at the country level and we applied this calculation at dis-aggregate levels for a better understanding of development at state, caste, communities levels. The HDI is widely accepted as a powerful analytical tool for planners, economists, policy makers and other sub-sects of developmental economics, which enables comparative assessment of the efficiency and effectiveness of development strategies among nations. It is an important concept for measurement and monitoring tool to potentiate maximizing human capabilities in its own advantage. The HDI assumes importance as it serves as a tool to monitor the interspatial status of human development and to identify problem areas where remedial actions can be directed. However, the practical usefulness and relevance of the HDI will be severely restricted if it is not used to facilitate disaggregated sections analysis and policy action. The concept of measurement of human development through HDI can very well be constructed as a major landmark in the sphere of development economics.

Hence, we aimed to measure the HDI among the oustees during the post dam period.

\subsection{Human Development Index of dam oustees}

There exist several studies on rehabilitation of dam oustees, although to our knowledge all of these are restricted to a qualitative assessment of the development in post rehabilitation period. The oustees, development can be measured more explicitly with the help of HDI. Human development index is viewed both as a means as well as an end for assessment of developmental index. Among the indicators used in our calculation, income is an indicator where as longevity and education, are means as well as end indicators. The HDI will give an objective insight towards the argument on rehabilitation of displaced people as it exhibits the real development of the displaced people and evaluates the success of rehabilitation package.

In order to measure the level of human development among the oustees, the sampled villages have been chosen as the units of study. Similar measures are applied here to derive HDI for 24 sampled villages treating each village as if it were a separate country.

However, due to paucity of information on gross enrolment ratio the study gives value to adult literacy rate. In regard to life expectancy, the study assumes the life expectancy of the Orissa state as the life expectancy of the people in the sampled villages. Income index is represented by the per capita income as estimated through primary survey. Accordingly, the indices are developed as follows:

For literacy Index minimum value is 0 and maximum value is 100 and it is calculated as follows: 
$\mathrm{E}_{1}-\mathrm{E}_{\min } / \mathrm{E}_{\max }-\mathrm{E}_{\min }$

Where, $\mathrm{E}_{1}=$ Actual value

$\mathrm{E}_{\min }=$ Minimum value

$\mathrm{E}_{\max }=$ Maximum value

For life expectancy at birth, maximum value is 85 years and minimum value is $25 y e a r s$.

$\mathrm{L}_{1}-\mathrm{L}_{\min } / \mathrm{L}_{\max }-\mathrm{L}_{\min }$

Where, $\mathrm{L}_{1}=$ Actual value

$\mathrm{L}_{\min }=$ Minimum value

$\mathrm{L}_{\max }=$ Maximum value

For calculating GDP per capita index (PPP US \$) maximum value is estimated as USD 52.60 and minimum as USD 1.85 .

Real per capita income of the displaced people in a village is calculated as follows:

$\left[\left\{\left(\mathrm{Y}_{1} / \mathrm{P}_{1}+\mathrm{Y}_{2} / \mathrm{P}_{2} \ldots \ldots \ldots \ldots \ldots \mathrm{Y}_{\mathrm{n}} / \mathrm{P}_{\mathrm{n}}\right) / \mathrm{n}\right\} / \mathrm{npi}\right] \times n g d p$

Where, $\mathrm{Y}_{1}, \mathrm{Y}_{2} \ldots \mathrm{Y}_{\mathrm{n}}=$ Income of each sampled household

$\mathrm{P}_{1}, \mathrm{P}_{2} \ldots \mathrm{P}_{\mathrm{n}}=$ Number of members in each sampled household

$\mathrm{n}=$ Total size of the population of the sampled households of a village

npi $=$ Percapita national income

ngdp = Percapita GDP (PPP US \$)

Percapita national income is USD 305.32 and percapita GDP is USD 52.60.

To calculate the income index the formula is

$\log \mathrm{Y}-\log \mathrm{Y} \min$

$\log \mathrm{Y} \max -\log \mathrm{Y} \min$

In the present paper the HDI is evaluated for oustees in sampled villages and tabulated (Table- 5).

HDI rates India with nations of medium level human development when compared with the rest of the world. The HDI of India is 0.558 (Census of India, 2001). Low human development is considered as less than 0.49 level, medium level ranges from 0.5 to 0.79 level and high human development is 0.8 and above. The HDI values are abysmally low across all the sampled villages when compared to the state of Orissa and India. The real per capita index and literacy index varied widely across the villages. The lowest literacy index was noted to 0.07 and the highest was 0.562 , whereas the lowest real per capita index was 215.9 and highest was 627.53 and the lowest income index was 0.128 and the highest was 0.306 . There was no correlation between villages with lowest literacy index with their income index and real per capita index.

The HDI values of the sampled villages are very low due to poor index in literacy, life expectancy and income. None of the villages qualifies to fall under the category of medium and high human development.

\section{Conclusion}

In this study we have evaluated the qualitative and quantitative aspects of the rehabilitation strategy on the dam induced displaced people of Indravati project in the state of Orissa, India.

The qualitative assessment was done by collecting data from respondents by interview and questionnaire. The provided data suggests a failure of rehabilitation strategy proposed by government. There were few positive outcomes of the rehabilitation strategy, such as the casteism based segregation got dissolved in post rehabilitation period. There was a downfall of joint family and on the other hand an increase in less practice of family planning in the post displacement period. The loss of agricultural land and the need of a livelihood increased the interest in getting education among oustees. A need for better livelihood was the driving force for better education, but lack of financial support prevented pursuing the interest. There was a significant decrease in the health status as well as the financial status of the respondents in post rehabilitation. The qualitative estimate revealed that the respondents had a better livelihood prior to displacement in comparison to the post displacement status. We also have analysed the opinion of respondents from villages to calculate the HDI for a quantitative evaluation of the status of oustees. The results obtained from HDI corroborated the qualitative evaluation of the respondents. The HDI of the displaced people due to Indravati hydel project in Orissa, India was much lower than the HDI of the state of Orissa as well as India. Moreover, the analysis of our results reflects on the necessity for improvising and revising the existing mandate of reforms for dam displacements implemented by the government. 
The context of our problem is to find out real development of displaced people.[42, 43] In order to take care of the displaced people and to mitigate the controversies among the government, policy makers and displaced people regarding the effectiveness of the rehabilitation package, it is the need to use the methodology of HDI. Human Development Index captures all dimensions of human development. It exhibits the extent of quality rehabilitation of displaced people and their real development. It is apparent that their exist disparities among sampled villages, this would help us to focus on the basic reasons and develop suitable mechanisms to deal with such situations. A well thought- out and integrated approach with adequate focus on the human development of oustees is the need of the hour, before the disparities and conflict gets aggravated. These controversies and challenges are successfully met with the help of HDI which reflects the real development. From the preceding analysis we can conclude that HDI by itself is the best available tool to measure the human development of displaced people as it provides an objective assessment of the situation thereby removing any kind of biasness in the results. An effort should be made to include some more variables, which relate to priorities and problems of oustees in finding out HDI. There are many implications that follow from our results and we assume that this methodology of HDI can be applied in other cases where large scale displacements take place such as installation of industry, mining etc.

References

[2]. Baboo, B., Big Dams and The Tribals:The case of the Hirakud Dam Oustees In Orissa. Social Action, 41(3), 1991, 288-303.

[3]. Dreze, J., Sen, A., India: Economic development and social opportunity.(USA Oxford University Press 1996).

[4]. Dams, W.C.o., Dams and development: A new framework for decision-making (The report of the World Commission on Dams).(London Earthscan Publications 2000).

[5]. Biswas, A.K., Tortajada, C., Development and large dams: A global prespective. International Journal of Water Resources Development, 17(1), 2001, 9-21.

[6]. Mander, H., Hemadri, R, Nagaraj, V., Dams, Displacement and Policy and Law in India., A Report of World commission on Dams. (Earthscan publications: London 1999).

[7]. Dams, W.C.o., Dams, Displacement and Policy and Law in India. , A Report of World commission on Dams. . (Earthscan publications: London 1999).

[8]. Satyanarayan, G., Development: Displacement and rehabilitation.(Jaipur Rawat Publications 1999).

[9]. Ota, A.B., Countering the impoverishment risk: The case of Rengali dam project, in A.B. Ota, \& Agnihotri, A., EditorInvoluntary displacement in dam projects. (Prachi Prakashan: New Delhi 1996). 150-178.

[10]. Parasuraman, S., Development projects, displacement and outcomes for dispalced: Two case studies. Economic and Political Weekly, 31(24), 1996, 1529-1532.

[11]. Picciotto, R., Van Wicklin, W., and Rice, E., Involuntary Resettlement: Comparative perspectives. . World Bank Series on Evaluation and Development. Vol. 2.(London Transaction Publishers 2001)

[12]. Commission, C.W., National register of large dams. Central water commission, Government of India 1994).

[13]. Briscoe, J., India's water economy: Bracing up for a turbulent future, in 4th Annual Partners Meet of IWMI-Tata Water Policy Research Program. 2005: Institute of rural managment, Anand.

[14]. De, S., Status paper on available database related to displacement situation in India. The Administrator, 43(1), 1998, 1-36.

[15]. Fernandes, W., Sixty years of development-induced displacement in India: Scale, impacts and the search for alternatives, in H.M. Mathur, EditorIndian social development report 2008. (Oxford University: Council for Social Development, New Delhi 2008a). 89102.

[16]. Fernandes, W., India's forced displacement policy and practice: Is compensation up to its function., in M.M. Cernea, Mathur, H.M., EditorCan Compensation Prevent Impoverishment? Reforming Resettlement through Investment and Benefit-Sharing. (Oxford University Press: New Delhi 2008b).

[17]. Mathur, H.M., Managing the consequences of development-induced displacement., in H.M. Mathur, EditorIndian social development report 2008. (Oxford Univeristy Press: Council for social development, New Delhi 2008). 179-95.

[18]. Bodh, A., 49 years after Nehru dedicated Bhakra dam to nation, displaced people awaits rehabilitation, in Times of India. 2012, The Times Group: New Delhi.

[19]. Hagler-Geard, T., Brazil's Belo Monte Dam to Displace Thousands in Amazon, in ABC News. 2012, ABC News: New York.

[20]. Stanley, J. Development-induced Displacement and Resettlement. 2004 [cited 2012 12 October]; Available from: http://www.forcedmigration.org/research-resources/expert-guides/development-induced-displacement-and-resettlement.

[21]. Dhagamwar, V., A Long Long Way from Home; Search for a Rehabilitation Policy, in E.G. Thukral, EditorBig dams displaced people rivers of sorrow rivers of change. (Sage Publications: New Delhi 1992). 187-198.

[22]. anguly-Thukral, E., Introduction, in E.G. Thukral, EditorBig dams displaced people: Rivers of sorrow, rivers of change. (SAGE: New Delhi 1992). 7-27.

[23]. Cernea, M.M., Malinowski Award Lecture: Social Organization and Development Anthropology. Human Organization, 54(3), 1996, 340-352.

[24]. Khagram, S., Dams and development: Transnational struggles for water and power.(New Delhi Oxford University Press 2005).

[25]. Altinbilek, D., The role of dams in development. International Journal of Water Resources Development, 18(1), 2002, 9-24.

[26]. McCully, P., Silenced rivers: the ecology and politics of large dams.(London Zed Books 2001).

[27]. Bartolome, L.J., De Wet, C., Mander, H., Nagraj, V.K., Displacement, Resettlement, Rehabilitation, Reparation and Development, Thematic Review I.3 prepared as an input to the World Commission on Dams. (World Commission on Dams: Cape Town, South Afrcia 2000). 1-86.

[28]. Mahapatra, L.K., Resettlement with participation: The Indian experience. The Eastern Anthropologist, 53(1\&2), 2000, 122-140.

[29]. Mankodi, K., Displacement and relocation: Problems and prospects, in W. Fernandes, Thukral, E.G., EditorDevelopment, Displacement and Rehabilitation. (Indian Social Institute: New Delhi 1989). 135-163.

[30]. Orissa, G.o., The Orissa resettlement and rehabilitation of project affected persons policy.(Water Resource Department, Bhubaneswar Government of Orissa 1994).

[31]. Patnaik, S.M., Tribe and displacement: Social implication of rehabilitation. Journal of Human Ecology, 11(4), 2000, 299-314. 
[32]. Herschy, R.W. Population Displacement Due to Dam Construction. Earth Sciences Series. Encyclopedia of Hydrology and Lakes 2013 [cited 2013; http://www.springerreference.com/docs/html/chapterdbid/30431.html].

[33]. Zhang, Y., He, D., Lu, Y., Feng, Y., Reznick, J., The influence of large dams building on resettlement in the Upper Mekong River. Journal of Geographical Sciences, 23(5), 2013, 947-957.

[34]. Carino, J., The World Commission on Dams: A Review of Hydroelectric Projects and the Impact on Indigenous Peoples and Ethnic Minorities. Cultural Survival Quarterly, 23(3), 2001, 53-56.

[35]. hah, Z.K., M. Dinesh., In the midst of the large dam controversy: objectives, criteria for assessing large water storages in the developing world. Water Resources Management, 22(12), 2008, 1799-1824.

[36]. Sharma, R.N., Involuntary displacement: A few encounters. Economic and Political Weekly, 31(24), 2003, 1533-1538.

[37]. Akça, E., Fujikura, R., Sabbağ, C., Atatürk Dam resettlement process: increased disparity resulting from insufficient financial compensation. International Journal of Water Resources Development, 29(1), 2013, 101-108.

[38]. Fujikura, R., Nakayama, M., The long-term impacts of resettlement programmes resulting from dam construction projects in Indonesia, Japan, Laos, Sri Lanka and Turkey: a comparison of land-for-land and cash compensation schemes. International Journal of Water Resources Development, 29(1), 2013, 4-13.

[39]. Antony, G.M., Rao, K.V, Balakrishna, N. , Suitability of HDI for assessing health and nutritional status. . Economic and Political Weekly, 36(31), 2001, 2976-2979.

[40]. report, H.d., Human Development Report, UNDP.(New York Oxford University Press 2001).

[41]. Report, H.D., Human Development Report 2006.(New York United Nations 2006).

[42]. Deshpande, N. Displace by the dam: A lifetime's harvest. INDIA TOGETHER,2010.

[43]. Nuwer, R. Hobbled on Energy, India Ponders a Multitude of Dams. A Blog about Energy and the Environment, The Newyork Times,2013.

Table 1: Depicting the change in the Social life of oustees from pre-displacement period to postdisplacement period.

\begin{tabular}{|c|c|c|c|c|c|c|c|c|c|c|c|c|}
\hline \multirow[t]{2}{*}{ Social aspects } & \multicolumn{2}{|c|}{ Caste distribution } & \multicolumn{3}{|c|}{ Family composition } & \multicolumn{2}{|c|}{ Family planning } & \multirow{2}{*}{ 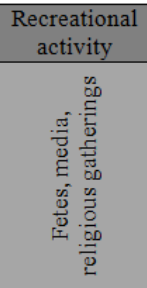 } & \multicolumn{4}{|c|}{ Social organizational participation } \\
\hline & 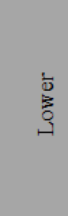 & 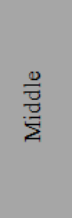 & 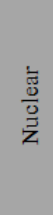 & $\stackrel{\vec{\Xi}}{\stackrel{\Xi}{\circ}}$ & 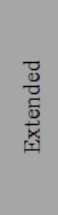 & 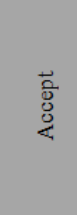 & $\frac{\vec{d}}{\stackrel{\vec{U}}{\mathscr{N}}}$ & & 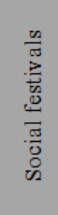 & 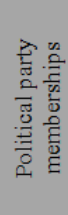 & 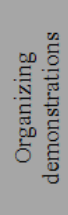 & 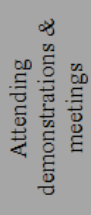 \\
\hline Pre-displacement & & & 43.8 & 39.8 & 16.4 & 77 & 23 & 93.2 & 67 & 44 & 57.3 & 72.6 \\
\hline Post- displacement & 27.7 & 72.3 & 72 & 22.5 & 5.5 & 40.6 & 59.4 & 58 & 32.7 & 14 & 29.6 & 27.4 \\
\hline
\end{tabular}

Table 2: Depicting the change in the educational level of oustees from pre-displacement period to post-displacement period

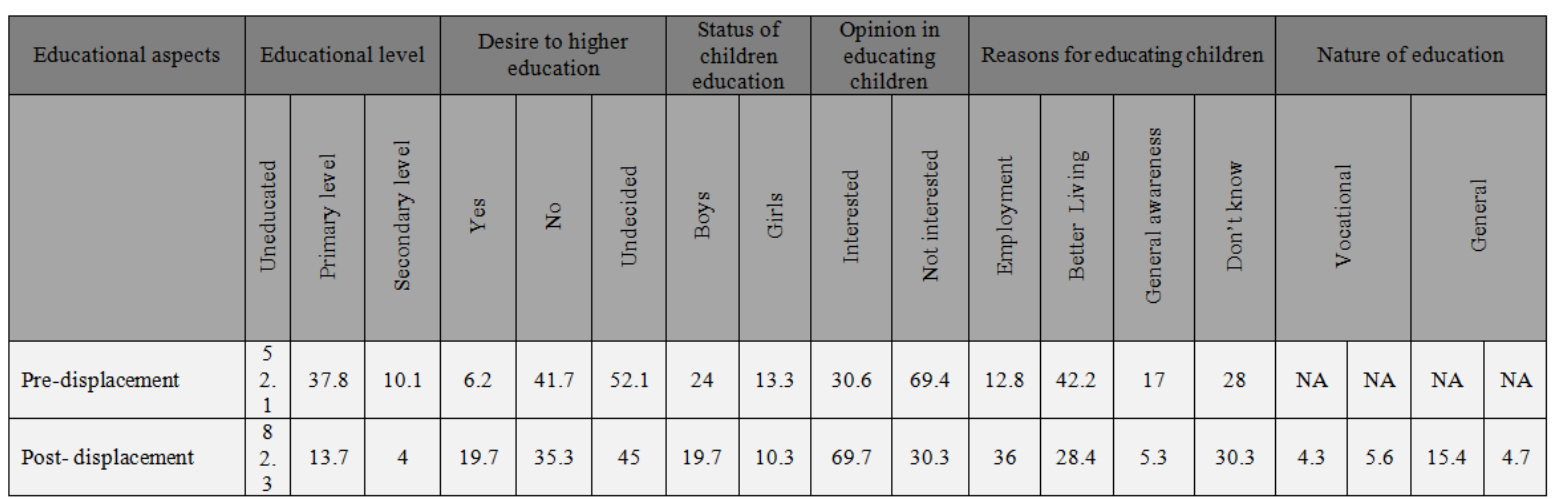

Table 3: Depicting the change in the healthcare of oustees from pre-displacement period to post-displacement period

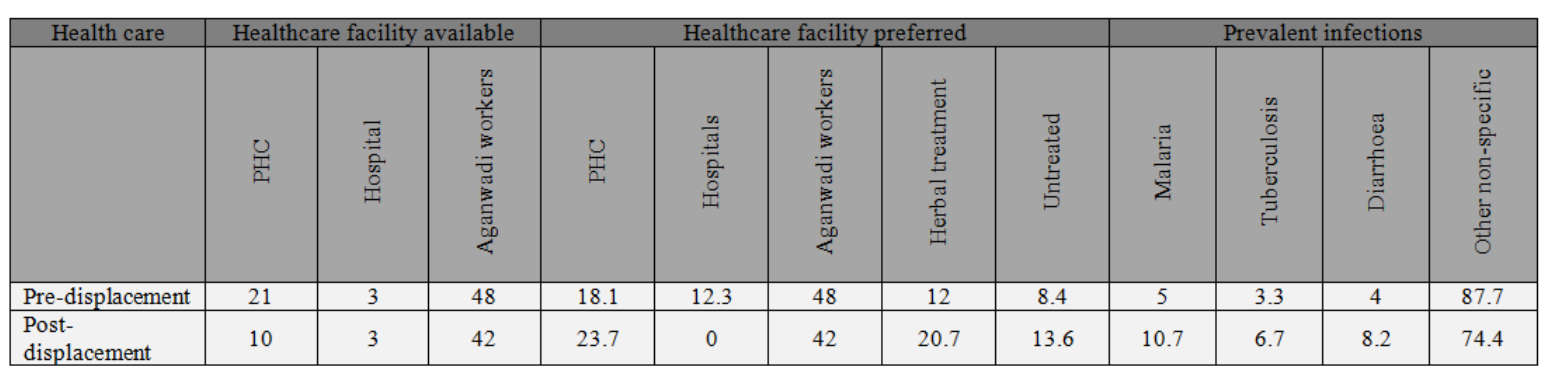


Developmental status of Indravati Dam oustees in India: A Human Development Index

Table 4: Depicting the change in the financial status of oustees from pre-displacement period to post- displacement period

\begin{tabular}{|c|c|c|c|c|c|c|c|c|c|c|c|c|c|c|c|c|c|c|c|c|}
\hline \multirow[t]{2}{*}{ Financial status } & \multicolumn{3}{|c|}{ Occupation } & \multicolumn{3}{|c|}{ Total income } & \multicolumn{6}{|c|}{ Expenditure pattern } & \multirow{2}{*}{ 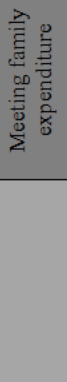 } & \multicolumn{3}{|c|}{ Meeting basic needs } & \multicolumn{3}{|c|}{$\begin{array}{l}\text { Means of } \\
\text { meeting needs }\end{array}$} & \multirow[t]{2}{*}{ 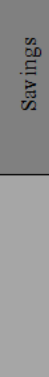 } \\
\hline & $\frac{\stackrel{0}{\Xi}}{\frac{3}{3}}$ & 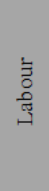 & 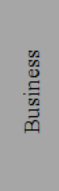 & $\begin{array}{l}\infty \\
\infty \\
m \\
m_{1}\end{array}$ & $\begin{array}{l}\text { कि } \\
\text { vi }\end{array}$ & $\frac{\infty}{v_{1}}$ & : & 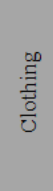 & 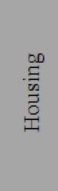 & 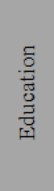 & 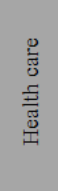 & 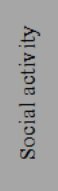 & & $\begin{array}{l}\stackrel{\infty}{\Xi} \\
\frac{\partial}{\Xi} \\
\end{array}$ & $\begin{array}{l}\overrightarrow{0} \\
8 \\
0\end{array}$ & $\begin{array}{l}\frac{\bar{\Phi}}{\bar{D}} \\
\frac{D}{\tilde{D}}\end{array}$ & 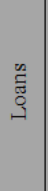 & 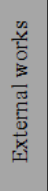 & 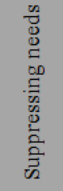 & \\
\hline $\begin{array}{l}\text { Pre- } \\
\text { displacement }\end{array}$ & 91 & 5.3 & 3.7 & 2.1 & 12.4 & 70.5 & 21.9 & 12.2 & 28.7 & 13.8 & 16.2 & 7.2 & 72 & 79.1 & 92.3 & 91.6 & 45 & 5.3 & 49.7 & 63 \\
\hline
\end{tabular}

Table 5: Depicting the Human Development Index of displaced people.

\begin{tabular}{|c|c|c|c|c|}
\hline Villages No. & Literacy Index & Real per Capita Index & Income Index & HDI value \\
\hline 24 & $0.2825 \pm 0.141$ & $327.76 \pm 98.32$ & $0.190 \pm 0.009$ & $0.335 \pm 0.010$ \\
\hline
\end{tabular}

